\title{
Keratotic and Pigmented Basal Cell Carcinoma
}

\author{
Arcot Rekha, R. Parimuthukumar, Apoorva Pratap, Jayanth X. Leo, V. M. Pai \\ Department of General Surgery, Sri Ramachandra Medical College, Chennai, India \\ Email: rekha_a@yahoo.com
}

Received 8 December 2014; revised 23 December 2014; accepted 5 January 2015

Copyright (C) 2015 by authors and Scientific Research Publishing Inc.

This work is licensed under the Creative Commons Attribution International License (CC BY). http://creativecommons.org/licenses/by/4.0/

c) (i) Open Access

\begin{abstract}
Background: Basal cell carcinomas or rodent ulcers are commonly seen in the tear zone of the face. It rarely mimics melanomas when pigmented. Aim: We review literature of this uncommon condition and discuss the therapeutic modalities. Case Report: An elderly lady sought attention for a pigmented lesion on her forehead. The case is presented because pigmented lesions and verrucous appearing lesions can also be due to basal cell carcinoma. Typically basal cell carcinoma appears in the tear zone of the face and it mostly affects sun exposed areas. Conclusion: While surgery remains the gold standard in treatment, other modalities can be offered in areas where vital structures cannot be sacrificed and in recurrent lesions.
\end{abstract}

Keywords

Basal Cell Carcinoma, Keratotic, Pigmented

\section{Introduction}

This non-melanocytic skin cancer comprising of basal cell carcinoma (BCC) and squamous cell carcinoma (SCC) is the most common form of skin cancer. It arises from the basal cells present in the lower layer of the epidermis. BCC is the most common over photo exposed areas of skin in direct proportion to the number of pilosebaceous units present in that area. It is a slow growing tumour that rarely metastasizes but can cause extensive destruction of the surrounding tissue and bone, referred to as ulcus rodens. Clinicians must be aware of the variants of BCC to avoid errors in diagnosis and management.

\section{Case Report}

A 80-year-old woman was admitted with the complaints of an ulcer over her forehead. The lesion initially started as a nodular lesion that increased in size over 2 months and formed an ulcer. The ulcer was around $3 \mathrm{~cm}$ 
in diameter with rolled edges. Due to its blackish appearance, a provisional diagnosis of either BCC or malignant melanoma was made. X-ray of the skull showed no bony destruction and chest X-ray was normal. Patient underwent wide local excision of the swelling followed by a z-plasty (Figure 1). The histology report confirmed the diagnosis of basal cell carcinoma. The patient was well at the monthly and yearly follow-up, with no recurrence or flap necrosis.

The difficulties in management include the ability to give a wide clearance margin and also the subsequent skin cover. In the event of bony extension an osseo myocutaneous flap may be needed.

Histology showed nests of BCC with palisading surrounded by a typical loose stroma (Figure 2). The evidence of keratotic and pigmentation is seen in the figures (Figure 3). Melanin in the dermal macrophages between the tumour nests shows the "pigmented" appearance clinically. Since the margins were free of tumour, there was no need for adjuvant therapy. Patient was counseled about the likelihood of similar lesions occurring in other sun exposed areas.

\section{Discussion}

Basal cell carcinoma is one of the most common cancers [1]. Due to its association with ultraviolet rays, photoexposed areas such as the forehead are the most common sites of developing BCC. The clinical variants include nodular (30\% - 75\%), superficial (10\% - 15\%) cystic, morpheiform and infiltrative (10\%) BCC [2]. Nodular

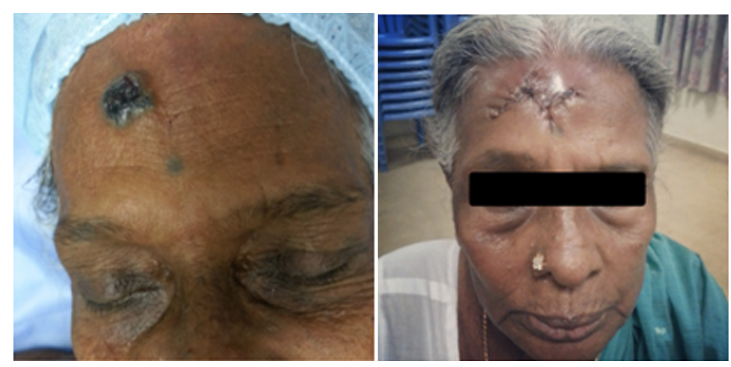

Figure 1. Show the pigment ulceronodular lesion and after z-plasty.

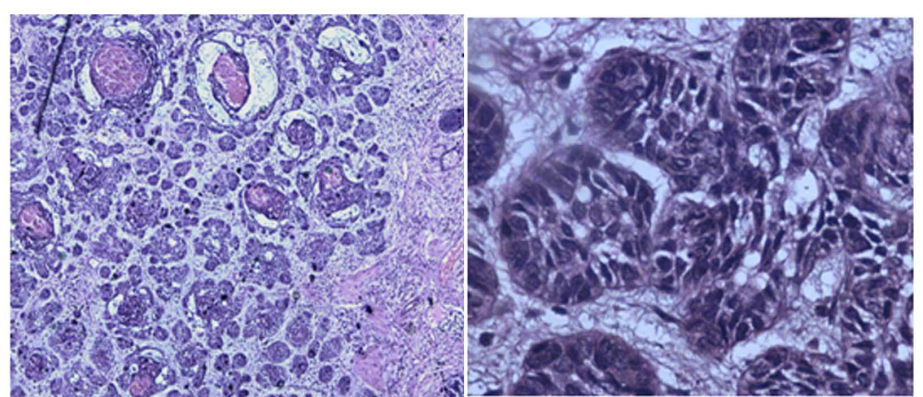

$10 \times$ magnification

$40 \times$ magnification

Figure 2. Showing the BCC with $10 \times$ and $40 \times$ magnification.

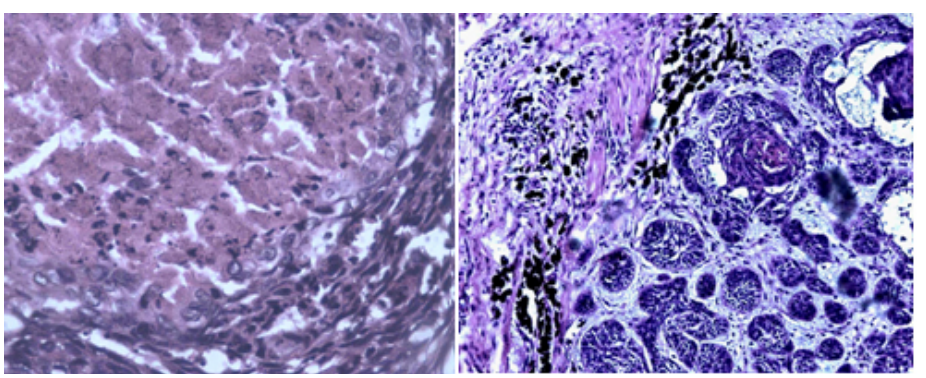

Figure 3. Showing the keratotic and pigment components. 
BCC compromises $60 \%$ - $80 \%$ of basal cell carcinomas and is most common over the skin of the forehead. Such tumours of the face have the propensity to invade the skull, nares, orbit or temporal bone thus leading to lethal meningitis. BCC may have solid, cystic, adenoid, keratotic, pigmented, infiltrating and sclerosing patterns. Pigmented BCC contains functional melanocytes producing melanin whereas keratotic BCC shows a pronounced squamous differentiation. The presence of melanophages does not influence the functional behavior of the tumours.

\section{Diagnosis}

The diagnosis of BCC is based on histology where the basaloid cells show a rim of pale cytoplasm surrounding round or oval nuclei with rough granulated chromatin.

The lesions rarely metastasize, although local invasion of bone is possible.

The goal of therapy for patients with BCC is removal of the tumor with the best possible cosmetic result [3]. By far, surgical modalities are the most studied, most effective, and most used BCC treatments.

Small nodular tumours $(<2 \mathrm{~mm})$ can be treated by laser vaporization, electrodessication or curettage. Although effective, these methods can result in loss of tissue samples for pathological confirmation. Mohs micrographic surgery is based on the principles of margin control and tissue sparing and is used most commonly for tumours located over the head and neck [3]. Standard surgical excision affords both tumour removal and histopathological examination.

Several topical agents show promise in the treatment of BCC.

Topical application of 5FU 5\% cream can be used to treat small superficial BCC. It interferes with DNA synthesis by blocking methylation of deoxyuridylic acid and inhibiting thymidylate synthetase and, subsequently, cell proliferation. In properly selected (e.g., thin) tumors, cure rates of approximately $80 \%$ have been obtained [4].

Imiquimod 5\% cream is effective for the treatment of non-facial superficial BCC. Several studies have shown imiquimod to be curative in all patients with superficial BCC if used twice daily and in $73 \%-82 \%$ of patients when used once a day for 6 - 12 weeks [5]-[9].

Intralesional inteferan alpha 2B is effective in small superficial and nodular BCC, limited by the cost, multiple visits needed and the flu like symptoms [6].

Tazarotene (receptor-selective acetylenic retinoid) can cause BCC regression by increasing apoptosis and by decreasing cell proliferation in the skin cancer cells. In a published article by Wilson, topically applied tazarotene gel was shown to decrease tumor size in $47 \%$ of cases, and in $53 \%$ of cases, the tumor was eliminated completely.

An investigational agent, GDC-0449, which is administered orally may be tried for more advanced, mulitifocal and metastatic BCC. This compound is a synthetic chemical designed to reproduce the properties of the naturally occurring compound cycloamine. GDC-0449 blocks the hedgehog pathway in cells. This pathway contains 2 genes, patched and smoothened, which lead to a known tumor promoting gene, GLI1. A change in any of these genes has been associated with the development of BCC [7]. GDC-0449 is given orally once a day. Its side effects include some loss of sense of taste and some loss of hair and weight. In the first clinical trial of GDC-0449, approximately $90 \%$ of the patients responded to treatment with tumor shrinkage or stabilization. Decreased amounts of GLI1 were found in the skin of patients after treatment [8].

The following is a list of treatments [10] [11] and their 5-year recurrence rates for primary BCCs:

- Surgical excision- $10.1 \%$

- Radiation therapy- $8.7 \%$

- Curettage and electrodesiccation-7.7\%

- Cryotherapy-7.5\%

- All non-Mohs modalities-8.7\%

- Mohs micrographic surgery-1.0\%

These rates are probably affected by the fact that most clinicians use cryotherapy, curettage, and desiccation mostly on smaller and better-demarcated lesions.

\section{Conclusion}

Pigmented BCC may mimic melanomas but have better prognosis. The surgeon needs to be familiar with this 
variant and also consider non-surgical options in select cases.

\section{References}

[1] Patterson, J.W. and Wick, M.R. (2006) Nonmelanocytic Tumors of the Skin. In: Atlas of Tumor Pathology, Series 4, Fascicle 4, Armed Forces Institute of Pathology, Washington DC, 46-68.

[2] Saldanha, G., Fletcher, A. and Slater, D.N. (2003) Basal Cell Carcinoma: A Dermatopathological and Molecular Biological Update. British Journal of Dermatology, 148, 195-202. http://dx.doi.org/10.1046/j.1365-2133.2003.05151.x

[3] Barry, J., Oon, S.F., Watson, R. and Barnes, L. (2006) The Management of Basal Cell Carcinomas. Irish Medical Journal, 99, 179-181.

[4] Love, W.E., Bernhard, J.D. and Bordeaux, J.S. (2009) Topical Imiquimod or Fluorouracil Therapy for Basal and Squamous Cell Carcinoma: A Systematic Review. Archives of Dermatology, 145, 1431-1438. http://dx.doi.org/10.1001/archdermatol.2009.291

[5] Geisse, J., Caro, I., Lindholm, J., Golitz, L., Stampone, P. and Owens, M. (2004) Imiquimod 5\% Cream for the Treatment of Superficial Basal Cell Carcinoma: Results from Two Phase III, Randomized, Vehicle-Controlled Studies. Journal of the American Academy of Dermatology, 50, 722-733. http://dx.doi.org/10.1016/j.jaad.2003.11.066

[6] Greenway, H.T., Cornell, R.C., Tanner, D.J., Peets, E., Bordin, G.M. and Nagi, C. (1986) Treatment of Basal Cell Carcinoma with Intralesional Interferon. Journal of the American Academy of Dermatology, 15, 437-443. http://dx.doi.org/10.1016/S0190-9622(86)70192-8

[7] Bale, A.E. and Yu, K.P. (2001) The Hedgehog Pathway and Basal Cell Carcinomas. Human Molecular Genetics, 10, 757-762. http://dx.doi.org/10.1093/hmg/10.7.757

[8] Von Hoff, D.D., LoRusso, P.M., Rudin, C.M., Reddy, J.C., Yauch, R.L., Tibes, R., et al. (2009) Inhibition of the Hedgehog Pathway in Advanced Basal-Cell Carcinoma. The New England Journal of Medicine, 361, 1164-1172. http://dx.doi.org/10.1056/NEJMoa0905360

[9] Berman, B. (2008) Scientific Rationale: Combining Imiquimod and Surgical Treatments for Basal Cell Carcinomas. Journal of Drugs in Dermatology, 7, s3-s6.

[10] Dandurand, M., Petit, T., Martel, P. and Guillot, B. (2006) Management of Basal Cell Carcinoma in Adults Clinical Practice Guidelines. European Journal of Dermatology, 16, 394-401.

[11] National Comprehensive Cancer Network (2011) NCCN Clinical Practice Guidelines in Oncology. Basal Cell and Squamous Cell Skin Cancers, 1. http://www.nccn.org/professionals/physician_gls/pdf/nmsc.pdf 
Scientific Research Publishing (SCIRP) is one of the largest Open Access journal publishers. It is currently publishing more than 200 open access, online, peer-reviewed journals covering a wide range of academic disciplines. SCIRP serves the worldwide academic communities and contributes to the progress and application of science with its publication.

Other selected journals from SCIRP are listed as below. Submit your manuscript to us via either submit@scirp.org or Online Submission Portal.
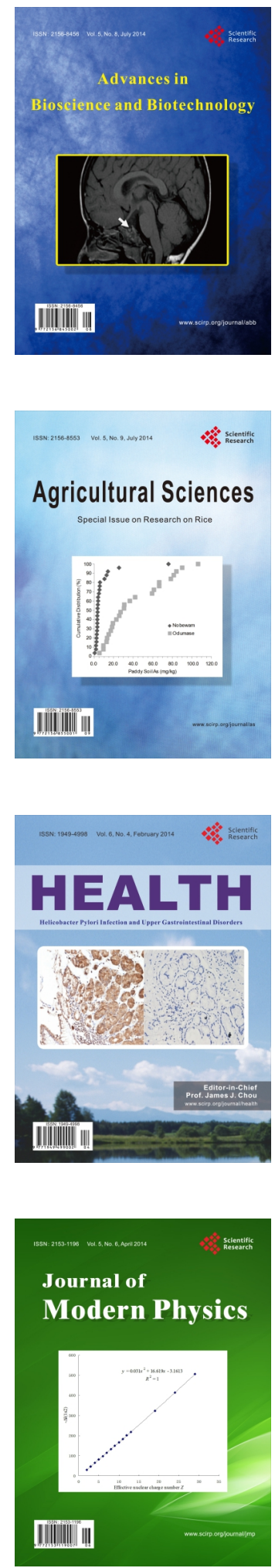
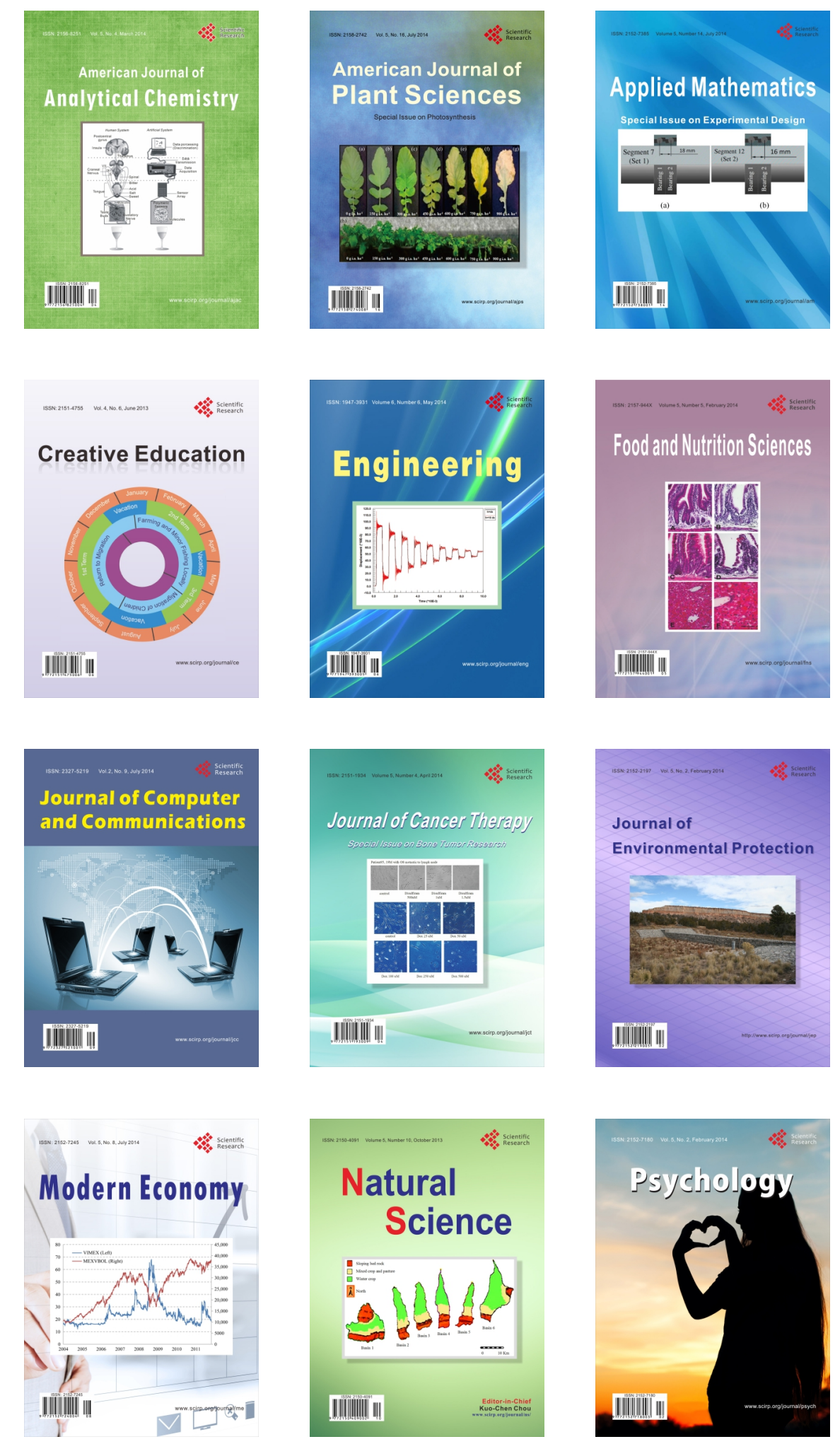